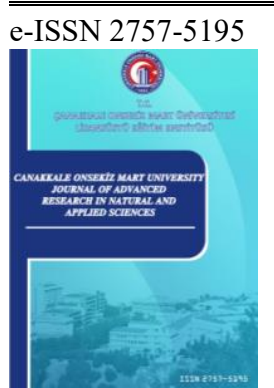

Çanakkale Onsekiz Mart University

Journal of Advanced Research in Natural and Applied Sciences

Open Access

\title{
Late Cenozoic Stress State in Gulf of Güllük and Surroundings, SW Anatolia
}

\author{
Erdem Gündoğdu ${ }^{1} *$, Alper Demirci ${ }^{2}$, Süha Özden ${ }^{3}$ \\ ${ }^{1}$ Department of Mining and Mineral Extraction, Çan Vocational School, Çanakkale Onsekiz Mart University, Çanakkale, Turkey \\ ${ }^{2}$ Department of Geophysical Engineering, Faculty of Engineering, Canakkale Onsekiz Mart University, Canakkale, Turkey \\ ${ }^{3}$ Department of Geological Engineering, Faculty of Engineering, Çanakkale Onsekiz Mart University, Çanakkale, Turkey
}

\begin{abstract}
Article History
Received: $\quad 28.04 .2021$

Accepted: $\quad 26.07 .2021$

Published: $\quad 15.12 .2021$
\end{abstract}

Research Article

\begin{abstract}
This study was performed with the aim of revealing the Late Cenozoic stress state of the Gulf of Güllük and close surroundings. In this study, the tectonic regime and stress states from the Pliocene to the present day were determined. Mesoscopic fault plane data were collected from outcrops at 19 different stations in the region between the Gulf of Güllük and Milas. Additionally, focal mechanism inverse solutions were calculated for 12 earthquakes larger than M:3.0 occurring from 2004 to 2015 to reveal the current tectonic regime. According to kinematic analysis results from fault assemblages and focal mechanism solutions for earthquakes, two tectonic regimes affected the region before the Pliocene and at present. In the first tectonic regime, strike-slip faulting developed under a NW-SE oriented compressional regime. There was an $\mathrm{R}$ ratio of 0.426 between the principal stress axes and this shows faulting had transtensional character. The region converted to a NE-SW oriented extensional regime dominated by normal faulting in the Quaternary. This currently effective extensional regime was understood from focal mechanism solutions of earthquakes developing in the region. The reason for this regime being effective is the rapid pull by the African plate on the Anatolian plate, which rides above the African plate, and horizontal extension in the Anatolian plate.
\end{abstract}

Keywords - Earthquake, focal mechanism, Gulf of Güllük, kinematic analysis, SW Anatolia

\section{Introduction}

Western Anatolia contains many active tectonic elements. The study area represents an area bounded by the main active tectonic elements of the Büyük Menderes Graben system to the north, the Gökova Fault Zone to the south, the Gulf of Güllük to the West and the Muğla Fault and Yatağan Fault to the west.

The kinematic and seismotectonic features of the Milas Fault, located in the study area, were investigated. The fault or faults with kinematic indicators were measured and reviewed and numerical analysis was performed. The presence of a two-stage tectonic regime was identified in the region. Additionally, extensional directions obtained from joint focal mechanism solution results for earthquakes and the extensional directions obtained as a result of kinetic studies were compared and the relationship with the effective extensional direction in W-SW Anatolia in the present day was investigated. The locations observed in field studies and obtained from kinematic data were discussed in light of faults represented on the active fault map and probable faults were evaluated in areas where the Milas Fault is not located. Recommendations were made about detecting the existence of these probable faults.

\footnotetext{
1 (D) erdem@comu.edu.tr

2 (iD) alperdemirci@comu.edu.tr

3 (D) ozden@ comu.edu.tr

*Corresponding Author
} 
Turkey is located at the intersection of three main lithospheric plates of the Eurasian, Arabian and African plates and is one of the world's most important seismic regions with more than 200 earthquakes with Mw>6.0 occurring in the last century (Emre et al., 2018; Kadirioğlu et al., 2018). With the effect of deformation occurring as a result of continental collision between the African, Arabian and Eurasian plates, the 4 main neotectonic elements of the North Anatolian Fault, East Anatolian Fault, Dead Sea Fault Zone and Cyprus-Hellenic Arc developed. As a result of northward movement of the Arabian and African plates, the Anatolian block has moved toward the west from the Mio-Pliocene to the present data and this movement, beginning the neotectonic period, caused many active faults to develop in the Anatolian block. The right lateral North Anatolian Fault and left lateral East Anatolian Fault developed along the north and east boundaries of the Anatolian block (Şengör, 1980). As a result of the effect of stretching and active deformation in Western Anatolia today with N-S extension, E-W striking depression areas (Gediz, Simav, Bakırçay-Soma, Edremit, Küçük Menderes, Büyük Menderes, Gökova) and elevated areas between these depressions (Kazdağları, Madra, Aydın, Menteşe, Bozdağları) can be observed (Kırkan et al., 2017).

In W-SW Anatolia, the Milas Fault, Yatağan Fault, Muğla Fault and Gökova Fault Zone are active faults located in the area between the Büyük Menderes Graben and Gulf of Gökova (Gulf of Güllük and surroundings) according to the Turkish Active Fault Map (Emre et al., 2018). Karabacak (2016), identified the Muğla Fault and Yatağan Fault as a single fault called the Muğla Fault.

The Muğla Fault has $25 \mathrm{~km}$ length, and is a normal fault with general strike from $105^{\circ}-140^{\circ}\left(\mathrm{N} 40^{\circ}-75^{\circ} \mathrm{W}\right)$ and dip from $60^{\circ}-65^{\circ}$ southwest (Emre et al., 2018). The Muğla Fault begins from Akçaova, passes north of Muğla provincial center to reach Gölcük (Emre, Duman, Özalp \& Elmac1, 2011; Emre et al, 2018; Duman, Emre, Özalp \& Elmac1, 2011). Muğla Fault had length of $30 \mathrm{~km}$ and proposed the maximum magnitude caused by earthquakes occurring on the Muğla Fault was Mw=6.71 (Emre et al., 2018).

The Yatağan Fault is a normal fault with $17 \mathrm{~km}$ length, general strike $297-342\left(\mathrm{~N} 18^{\circ}-63^{\circ} \mathrm{W}\right)$ dipping $60^{\circ}-65^{\circ}$ northwest. The Yatağan Fault begins south of Yatağan county and continues along Şahinler, Kağıbağ, Bozüyük, Gökpınar, Bahçeyaka, and Paşapınar (Emre et al., 2018; Duman et al., 2011). It was proposed that the maximum magnitude of an earthquake which may occur along the Muğla Fault was Mw=6.48 (Emre et al., 2018).

The Milas Fault with total $39 \mathrm{~km}$ length, comprises two segments of the Karakuyu segment with $25 \mathrm{~km}$ length and the Beçin segment with $14 \mathrm{~km}$ length. The Karakuyu segment follows the line of EğridereHisarcık-Karakuyu-Menteş and is a right lateral strike slip fault with general strike $292^{\circ}-309^{\circ}\left(\mathrm{N} 51^{\circ}-68^{\circ} \mathrm{W}\right)$ dipping $87^{\circ}-90^{\circ}$. The Beçin segment follows the line from Beçin-Kalınağ 1 l-Kayadere and is a right lateral strike slip fault with general strike from $295^{\circ}-307^{\circ}\left(\mathrm{N} 53^{\circ}-65^{\circ} \mathrm{W}\right)$ and dip of $87^{\circ}-90^{\circ}$ (Emre et al., 2018; Duman et al., 2011). All structural elements in the region are active faults with potential to produce earthquakes. In this study, the Late Cenozoic stress state for the Gulf of Güllük and close surroundings including active faults (Figure 1) was revealed using both kinematic analysis of fault assemblages and inverse solutions of earthquake focal mechanisms. 


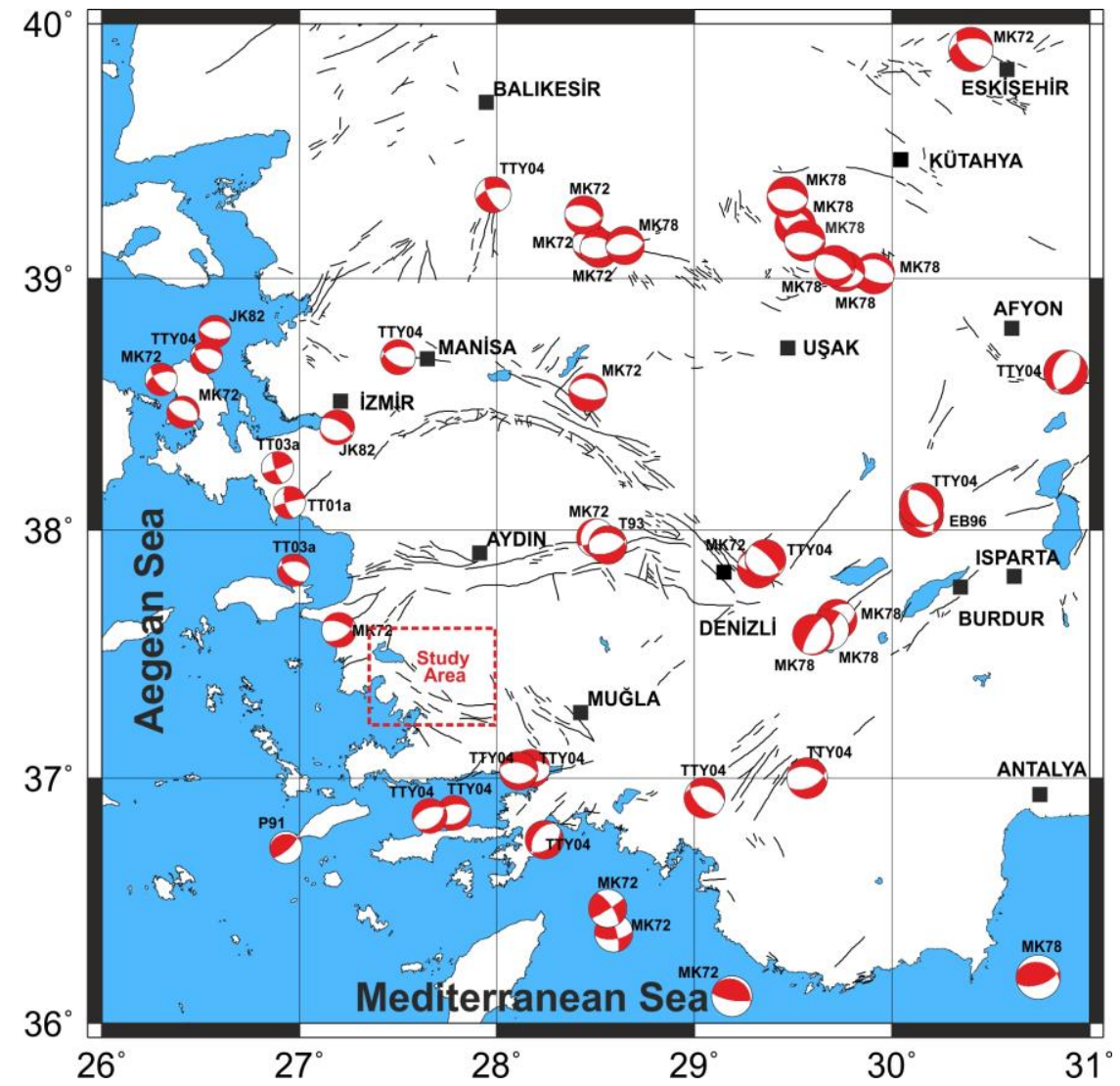

Figure 1. Seismotectonic map of the western Anatolian (Tan, Tapırdamaz \& Yörük, 2008 and references therein).

\section{Materials and Methods}

\subsection{Method used for Kinematic Analysis of Fault Assemblages}

First determined by Carey (1979) and then developed by Carey-Gailhardis \& Mercier (1987), kinematic analysis is a numerical analysis method using markers located on fault planes determining the form of movement (lineations, dip direction, dip amount, slip amount) in areas where the type of geological unit and outcrop conditions are appropriate. Analyses performed with the aid of data obtained from these markers reveal the behavior and form of deformation in field studies. Generally, movement planes extend in three perpendicular planes along the three main directions ending in polar points, with the three main stress directions, axes of the stress ellipsoid formed by maximum compressive stress $(\sigma 1)$, intermediate stress axis $(\sigma 2)$ and smallest stress component $(\sigma 3)$, changing linked to the discontinuity and heterogeneity of the material. For the movement direction on each fault in this situation, the principal stress $\sigma 1$ is the compressional region and $\sigma 3$ is the extensional region as revealed by Angelier \& Mechler (1977).

For each measured slip line, the stress on the plane $(\sigma 1)$ is determined as $\sigma 1=\sigma n i+\tau$. The angle between the predicted offset vector in the above hypothesis $(\tau \mathrm{i})$ and the observed offset vector $(\mathrm{Si})$ approaches 0 . The ( $\tau i$ ) component is a function of four parameters. These are the three Euler angles given by the three main stress directions according to a geographic reference point and the $\mathrm{R}$ ratio between principal stresses (Carey, 1979, Carey-Gailhardis and Mercier, 1987). $\mathrm{R}=(\sigma 2-\sigma 1) /(\sigma 3-\sigma 1)$. Here, $\sigma 1, \sigma 2$, and $\sigma 3$ are the three main stress values for compression, intermediate and extension. The R value changes between $(\sigma 2=\sigma 3)$ and $(\sigma 1=$ $\sigma 2)$ and has a value from 0 to 1 . The $R$ value provides information about the type and components of faulting. In the situation where the $\mathrm{R}$ value is 0 , there is normal faulting which is a product of an extensional regime; when it is close to 1 there is reverse faulting which is a product of a compressional regime. If the $\mathrm{R}$ value is close to $0(0<R<0.15)$ it represents the transition from strike slip faulting to normal faulting; if it is 
close to $1(0.85<R<1)$ it represents the transition from strike slip faulting to normal faulting. If the $R$ value is $0.45<\mathrm{R}<0.55$. strike slip faulting is present. Again if the $\mathrm{R}$ value is smaller than $0.45(0.15<\mathrm{R}<0.45)$, it represents a transtensional regime; when it is larger than $0.55(0.55<\mathrm{R}<0.85)$ it represents at transpressional regime (Özden, Över, Kavak, \& İnal, 2008). The three-axis stress situation of a normal faulting regime may be determined according to the $\mathrm{R}$ ratio. Stations giving normal faulting solutions are expected to have $\mathrm{R}$ values $(0.15<\mathrm{R}<0.85)$. Contrarily, normal faulting may be considered to develop as two axes and radial (linked to gravity) (Carey, 1979; Carey-Gailhardis \& Mercier 1987).

When differentiating tectonic deformation stages from each other, in addition to the directions of principal stress axes and ratio between principal stress axes, data from fault planes overlapping in the field, crosscutting fault-offset data, geodynamic evolution of Western Anatolia and comparisons with similar studies about this topic were used.

\subsection{Method used for Inverse Solution of Earthquake Focal Mechanisms}

The focal mechanism solutions for $11(\mathrm{M}>3)$ earthquakes used in the study were determined using the ZsacWin program (Y1lmazer, 2003) based on Dreger's (2002) inverse solution code and HYPO71 (Lee \& Lahr, 1972) location analysis. In the study with first movement polarity analysis was used for only 1 earthquake solution and a total of 12 earthquake source parameters were calculated. Full wave forms from several broad band stations recording regional and local distances were used in the method. The study chose threecomponent broad band station data with high signal/noise ratio and redetermined earthquake depths with the grid-search algorithm. Generally, solutions used $0.05-0.1 \mathrm{~Hz}$ interval band-pass filters. Final focal mechanism solutions were determined by noting the variance reduction parameters representing the compatibility between synthetic and observed wave forms.

In the regional moment tensor inverse solution technique, the moment tensor is a mathematical expression generalizing the conjugate force pairs at a point source which includes important information about the scalar-seismic moment, orientation and source mechanism. Generally, moment tensor parameters may be solved with data from a single three component station, but the inclusion of more stations in the analysis significantly improves the stability of results (Dreger \& Helmberger, 1993). In the analysis, a point source approach was used in space and time environments as seismic source.

$\mathrm{Un}(\mathrm{x}, \mathrm{t})=\operatorname{MijGni}, \mathrm{j}(\mathrm{x}, \mathrm{z}, \mathrm{t})$

The equation shows $\mathrm{U}$ as the ground movement component, while $\mathrm{G}$ is the Green function representing crustal structure. Additionally, the source station distance is $\mathrm{x}$, while the source depth is $\mathrm{z}$, and $\mathrm{M}$ includes the scalar seismic moment components. The basis of the method is to explain low frequency portions of the waveforms recorded at seismic stations within regional distance by the linear least squares solution to Equation 1 at depth determined by the assumption that the crustal structure is adequately known.

With the aim of determining the quality of the inverse solution, a variance criterion checking the compatibility between observed and calculated data is used. The variance reduction (VR) $(\max =100)$ is directly proportional to the solution quality.

$V R=\left(1-\sum \frac{\sqrt{\left(o b s_{i}-c a l_{i}\right)^{2}}}{\sqrt{o b s_{i}^{2}}}\right) x 100$

In conclusion, noting the VR parameter shown in Equation 2, the target is to iteratively reach the optimum solution and finally determine the fault plane parameters (strike, dip, rake) from this solution. 


\section{Results and Discussion}

\subsection{Kinematic Analysis Results}

When the geological units in the study area are examined, units appear to be dominantly from before the Miocene. Pre-Miocene units are simplified on the geological map, these units are grouped among themselves and assessed as basement units. Units from the Miocene period are observed around Didim county and surroundings, south and southwest of Milas county and west of Bodrum county. Quaternary units are observed southwest of Lake Bafa and around Milas.

Kinematic analysis measurements from a total of 19 stations included 18 in pre-Miocene units and 1 from a Miocene unit (Figure 2 and Table 1). Kinematic data from 136 fault planes measured at a total of 21 stations identified the presence of 2 different tectonic regimes. These tectonic regimes are a NW/SE compressional regime (SS1) and a NE/SW extensional regime (SS2), from older to younger (Figure 3). When differentiating these tectonic regime types (deformation stages), many parameters were considered and the study worked backwards in time beginning with the final tectonic regime. Tectonic regimes were determined by considering the principal strain axes obtained from kinematic analysis results and the ratio of principal strain axes. This topic was compared with previous studies, similar and same-age fields in order to differentiate deformation stages, especially in west-central Anatolia and the Aegean Extension region and this was a large factor in creating this chronological narrative for geodynamic evolution in western Anatolia.

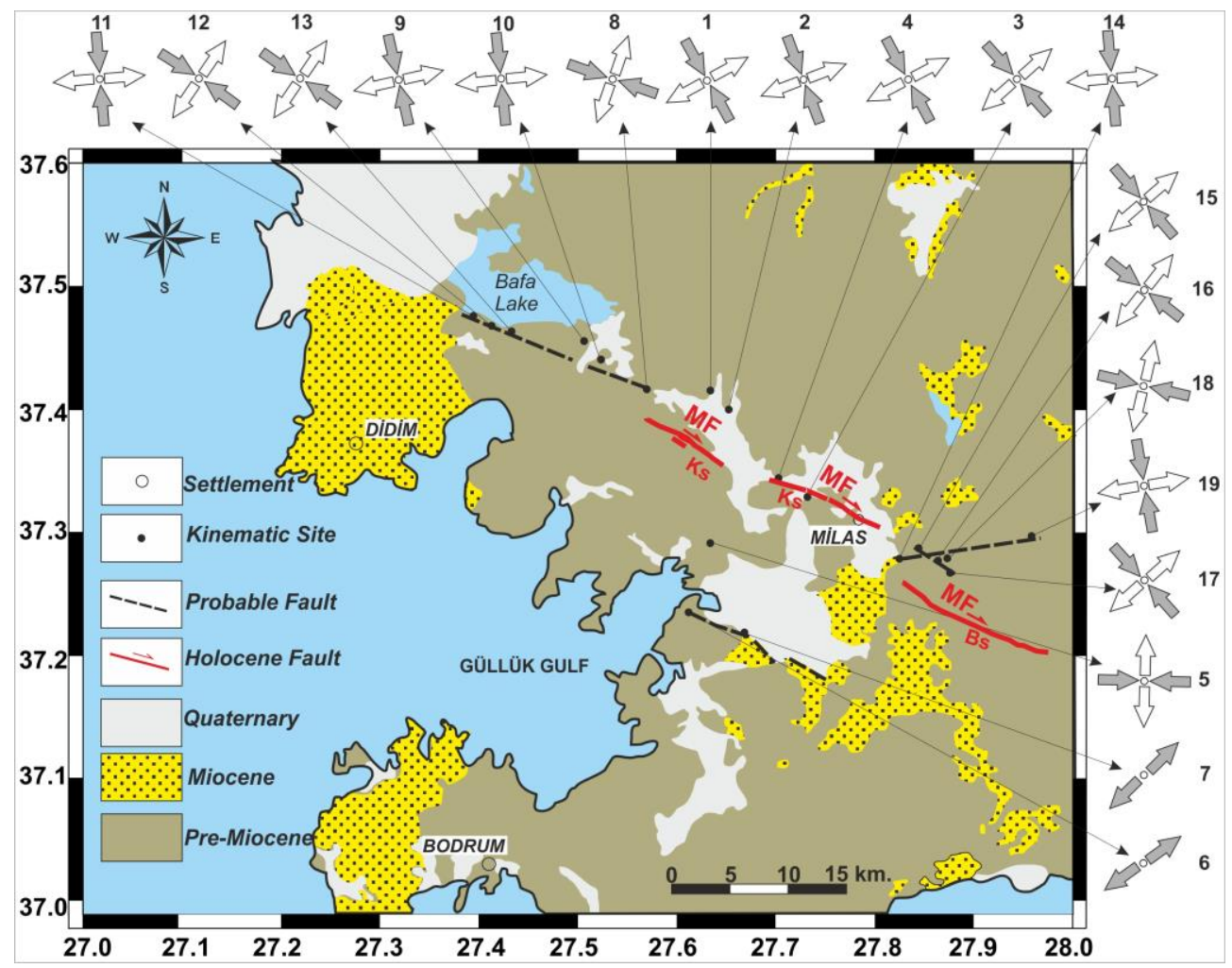

Figure 2. Geological and Active Fault map of the Gulf of Güllük and Surroundings (Emre et al., 2011; Duman et al, 2011). 
Table 1.

Parameters of fault measurement sites.

\begin{tabular}{|c|c|c|c|c|}
\hline Sites & UTM (Longitude) & UTM (Latitude) & Age & Litology \\
\hline 1 & $35 \mathrm{~S} 0555717$ & 4140683 & Paleozoic & Phyllite \\
\hline 2 & $35 \mathrm{~S} 0557646$ & 4140086 & Paleozoic & Phyllite \\
\hline 3 & 35S 0563799 & 4133534 & Paleozoic & Phyllite \\
\hline 4 & $35 \mathrm{~S} 0561867$ & 4134588 & Paleozoic & Phyllite \\
\hline 5 & 35S 0555737 & 4128791 & U. Paleocene-Eocene & Metaclastics, Metacarbonates \\
\hline 6 & 35S 0553690 & 4121855 & Mesozoic & Schist, Calcschist \\
\hline 7 & 35S 0559097 & 4120843 & Miocene & Terrestrial Crumb \\
\hline 8 & $35 \mathrm{~S} 0550451$ & 4142062 & Upper Paleozoic & Phyllite \\
\hline 9 & 35S 0545622 & 4145099 & Upper Paleozoic & Phyllite \\
\hline 10 & $35 \mathrm{~S} 0544327$ & 4146177 & Upper Paleozoic & Phyllite \\
\hline 11 & $35 \mathrm{~S} 0534470$ & 4148661 & Mesozoic & Marble \\
\hline 12 & 35S 0536039 & 4148188 & Mesozoic & Marble \\
\hline 13 & 35S 0537961 & 4147572 & Mesozoic & Marble \\
\hline 14 & 35S 0572913 & 4126872 & Mesozoic & Marble \\
\hline 15 & 35S 0574659 & 4127734 & Mesozoic & Marble \\
\hline 16 & $35 S 0576036$ & 4127012 & Mesozoic & Marble \\
\hline 17 & 35S 0576034 & 4127018 & Mesozoic & Marble \\
\hline 18 & 35S 0578355 & 4128628 & Upper Paleozoic & Schist \\
\hline 19 & $35 \mathrm{~S} 0583925$ & 4128831 & Upper Paleozoic & Schist \\
\hline
\end{tabular}

\subsubsection{NW/SE compressional regime (SS1)}

This type of faulting is observed in nearly all locations in the study area encompassing the whole area from Lake Bafa to the Milas Fault. This regime is represented by 17 observation points (stations apart from 6 and 7) and was measured on a total of 121 fault planes. Here the main stress axis $(\sigma 1)$ and minimum stress axis $(\sigma 3)$ are horizontal while the intermediate stress axis is vertical $(\sigma 2)$. Due to this, the tectonic regime type is strike slip faulting. When the measured data are assessed together, the maximum principal stress axis $(\sigma 1)$ is $136^{\circ} / 19^{\circ}$; while the minimum principal stress axis $(\sigma 3)$ is $232^{\circ} / 7^{\circ}$. The $\mathrm{Rm}$ ratio is 0.426 (Figure 3 and Table 2). These results show that compression in the region was $(\sigma 1) \mathrm{N} 44^{\circ} \mathrm{W}$. The $\mathrm{R}$ ratio was between 0.45 and 0.55 close to pure strike slip faulting.

\subsection{2. $\mathrm{NE} / \mathrm{SW}$ extensional regime (SS2)}

This type of faulting is the youngest tectonic regime observed in the study area and is observed at stations 6 and 7. This regime is represented by measurements on a total of 15 fault planes at 2 observation points. Here the intermediate stress axis $(\sigma 2)$ and minimum principal stress axis $(\sigma 3)$ are horizontal, while the maximum principal stress axis $(\sigma 1)$ is vertical. For this reason, the tectonic regime type is close to normal faulting. When the measured data are assessed together, the minimum principal stress axis is $(\sigma 3) 230^{\circ} / 8$. The $\mathrm{Rm}$ ratio is 0.416 (Figure 3 and Table 2). These results show that the extensional (opening) direction in the region was $(\sigma 3) \mathrm{N} 50^{\circ} \mathrm{E}$.

Mesoscopic fault planes belonging to tectonic deformations observed in the study area are shown in Figure 4 and Figure 5. In addition, the section of the road cut showing the last tectonic deformation phase is shown in Figure 6. 


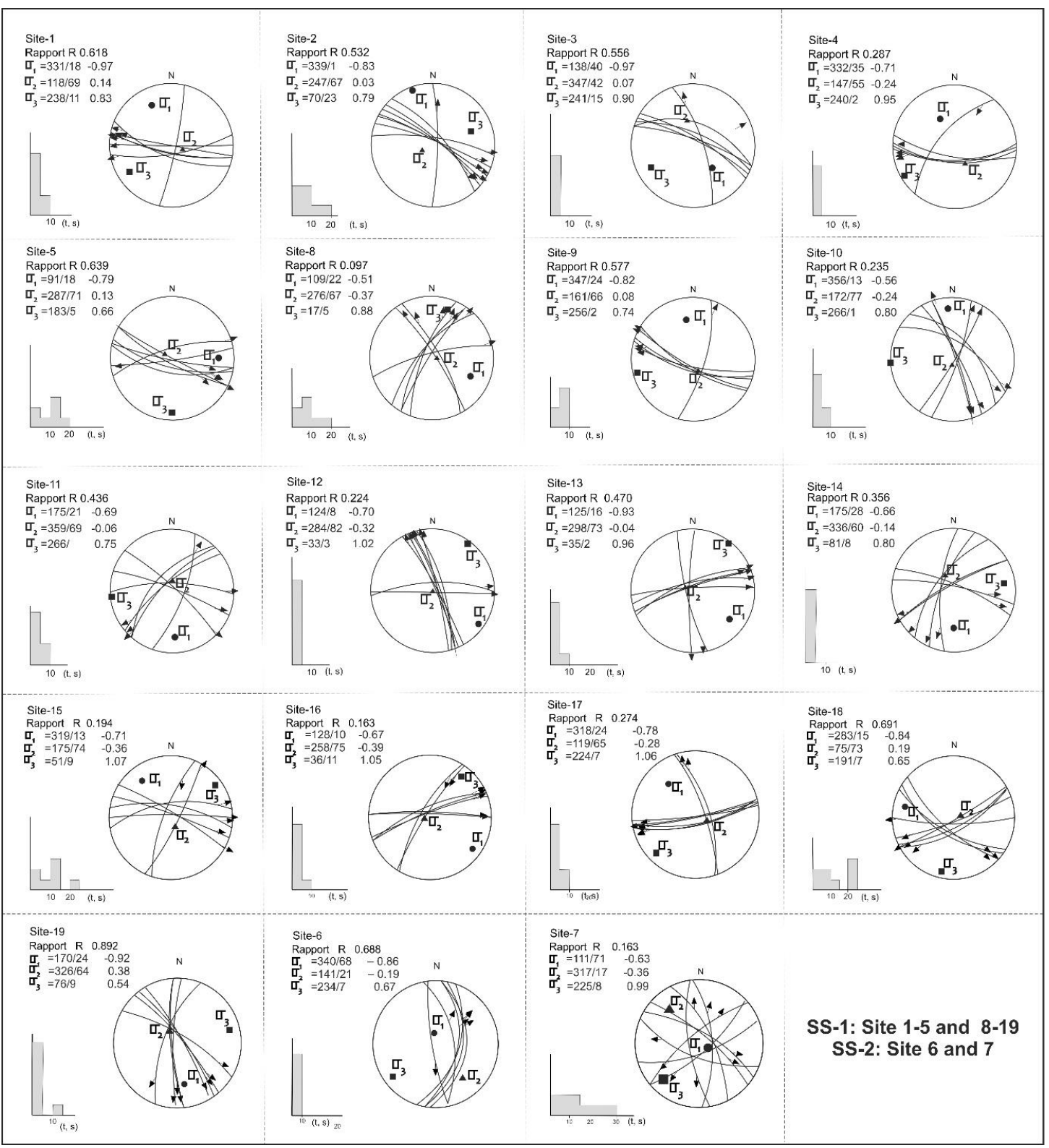

Figure 3. Results of kinametic analysis. Lower hemisphere stereoplots showing, SS1: NW-SE compressional regime (site 1-5 and 8-19), SS2: NE-SW extensional regime (site 6 and 7). 
Table 2.

Results of stress tensor inversions for slip datas.

\begin{tabular}{|c|c|c|c|c|c|}
\hline (a) Sites & $\sigma 1(\mathrm{Az} / \mathrm{dip})$ & $\sigma 2(\mathrm{Az} / \mathrm{dip})$ & $\sigma 3(\mathrm{Az} / \operatorname{dip})$ & $\mathrm{R}$ & $\mathrm{N}$ \\
\hline 1 & $331 / 18$ & $118 / 69$ & $238 / 11$ & 0.618 & 8 \\
\hline 2 & $339 / 1$ & $247 / 67$ & $70 / 23$ & 0.532 & 8 \\
\hline 3 & $138 / 40$ & $347 / 46$ & $241 / 15$ & 0.556 & 6 \\
\hline 4 & $332 / 35$ & $147 / 55$ & $240 / 2$ & 0.287 & 5 \\
\hline 5 & $91 / 18$ & $287 / 71$ & $183 / 5$ & 0.639 & 7 \\
\hline 8 & $109 / 22$ & $276 / 67$ & $17 / 5$ & 0.097 & 8 \\
\hline 9 & $247 / 24$ & $161 / 66$ & $256 / 2$ & 0.577 & 5 \\
\hline 10 & $356 / 13$ & $172 / 77$ & $266 / 1$ & 0.235 & 7 \\
\hline 11 & $175 / 21$ & $359 / 69$ & $266 / 1$ & 0.436 & 7 \\
\hline 12 & $124 / 8$ & $284 / 82$ & $33 / 3$ & 0.224 & 8 \\
\hline 13 & $125 / 16$ & $298 / 73$ & $35 / 2$ & 0.470 & 7 \\
\hline 14 & $175 / 28$ & $336 / 60$ & $81 / 8$ & 0.356 & 7 \\
\hline 15 & $319 / 13$ & $175 / 74$ & $51 / 9$ & 0.194 & 7 \\
\hline 16 & $128 / 10$ & $258 / 75$ & $36 / 11$ & 0.163 & 7 \\
\hline 17 & $318 / 24$ & $119 / 65$ & $224 / 7$ & 0.274 & 8 \\
\hline 18 & $283 / 15$ & $75 / 73$ & $191 / 7$ & 0.691 & 8 \\
\hline 19 & $170 / 24$ & $326 / 64$ & $76 / 9$ & 0.892 & 8 \\
\hline SS.1 & \multicolumn{4}{|c|}{$\sigma 1=136^{\circ} / 19^{\circ}$ and $\sigma 3=232^{\circ} / 7^{\circ} \quad R m=0,426$} & 121 \\
\hline (b) Sites & $\sigma 1(\mathrm{Az} / \mathrm{dip})$ & $\sigma 2(\mathrm{Az} / \mathrm{dip})$ & $\sigma 3(\mathrm{Az} / \mathrm{dip})$ & $\mathrm{R}$ & $\mathrm{N}$ \\
\hline 6 & $340 / 68$ & $141 / 21$ & $234 / 7$ & 0.668 & 6 \\
\hline 7 & $111 / 71$ & $317 / 17$ & $225 / 8$ & 0.163 & 9 \\
\hline SS.2 & \multicolumn{4}{|c|}{$\sigma 2=319^{\circ} / 19^{\circ}$ and $\sigma 3=230^{\circ} / 8^{\circ} \mathrm{Rm}=0,416$} & 15 \\
\hline$S F M$ & \multicolumn{4}{|c|}{$\sigma 2=327^{\circ} / 28^{\circ}$ and $\sigma 3=233^{\circ} / 6^{\circ} \mathrm{Rm}=0,498$} & 12 \\
\hline
\end{tabular}



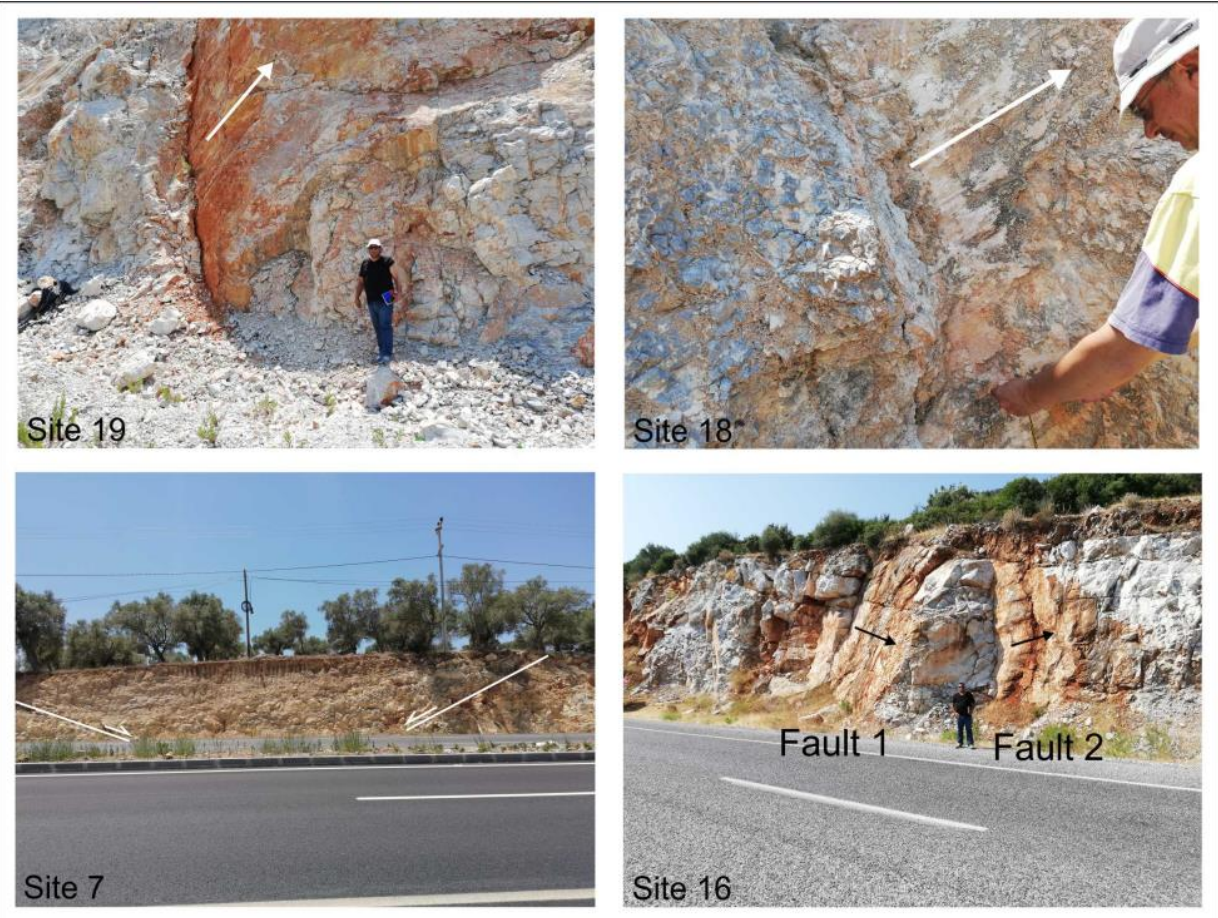

Figure 4. Mesoscopic fault plane examples showing tectonic deformation in the study area
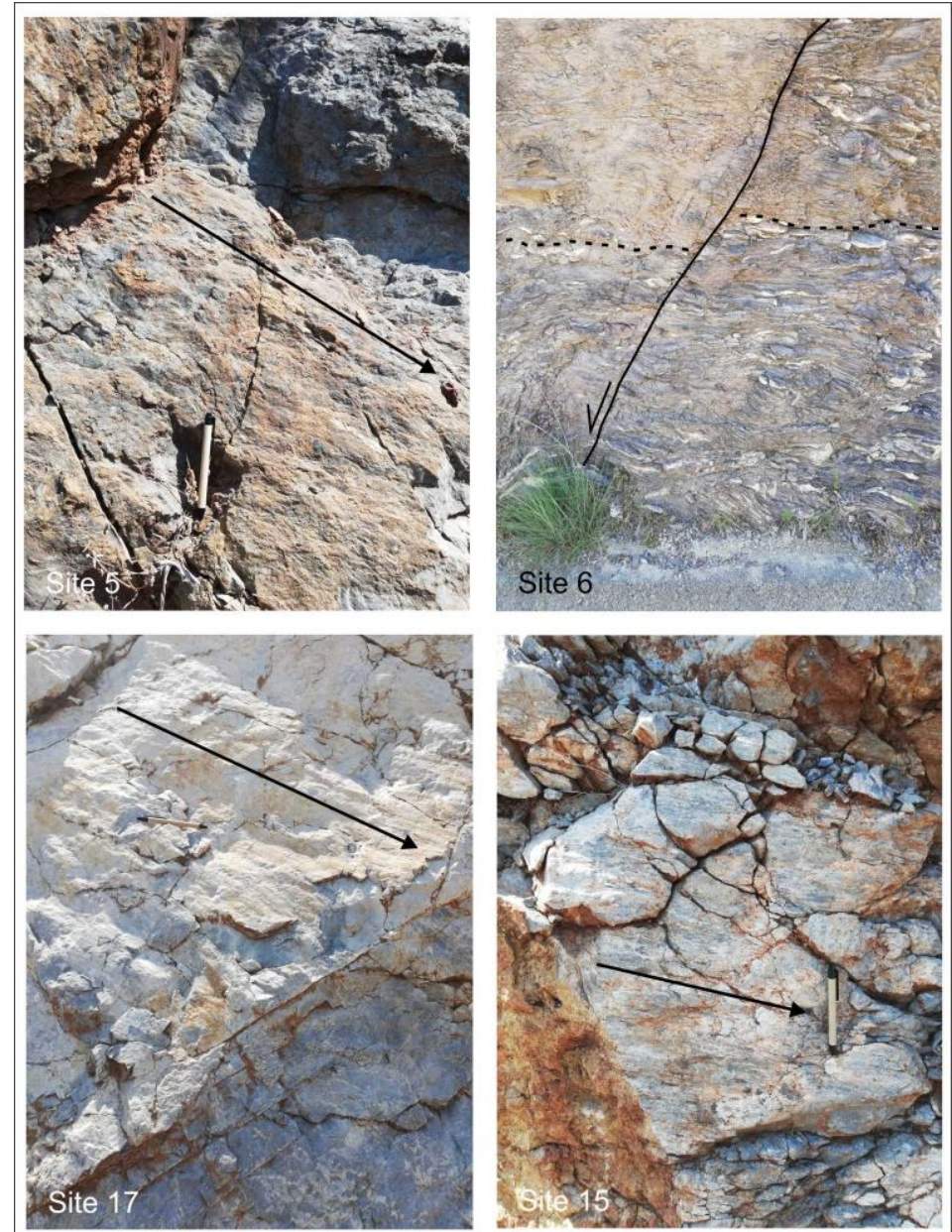

Figure 5. Mesoscopic fault plane examples showing tectonic deformation in the study area 


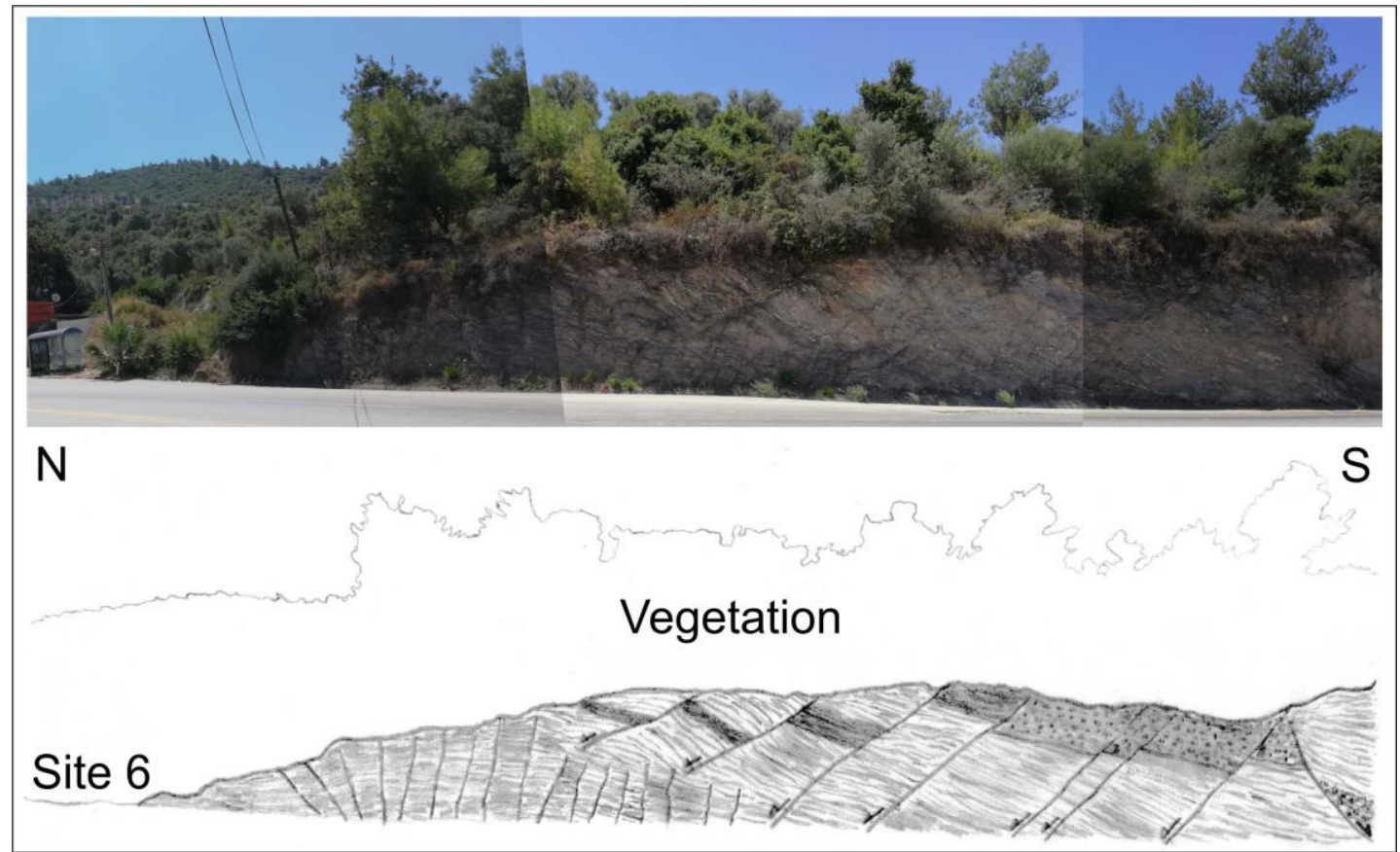

Figure 6. Roadcut section showing final tectonic deformation stage in the study area

\subsection{Results for Earthquake Focal Mechanisms}

Inverse solution processes completed using data from minimum 5 and maximum 11 stations in the study area and close surroundings showed variation in the VR value from 51 to 80 , used as reliability parameter for the solutions. The first arrival polarity for earthquakes with the smallest magnitude among earthquakes used in the study and shown only by $\mathrm{K}$ was used for solutions (Table 3). Especially for solutions using many stations, the VR value interval can be said to be very adequate. The majority of earthquakes solved in the region in general indicate normal faults with oblique offset component or strike slip faults with small normal component (Figure 7). After solutions, it was considered that the nodal planes close to E-W orientation represent the true plane. These planes nearly all present different degrees of normal component in accordance with the extensional regime in the region. Among these earthquakes, 3 earthquakes named $\mathrm{E}, \mathrm{C}$ and $\mathrm{L}$ displaying more dominant normal faulting compared to the others were observed to be located along the south boundary of the Sarıçay Plain southwest of the Milas Fault. The focal mechanism solutions for these three earthquakes are compatible with the NNE-SSW extensional regime in the region, indicating the presence of normal faults with NE-dipping oblique offset component. However, the focal mechanism solutions for earthquakes $\mathrm{A}, \mathrm{B}, \mathrm{H}$ and $\mathrm{K}$ observed with epicenter above or close to the Milas fault represent more right-lateral strike slip fault movements (Figure 7). 


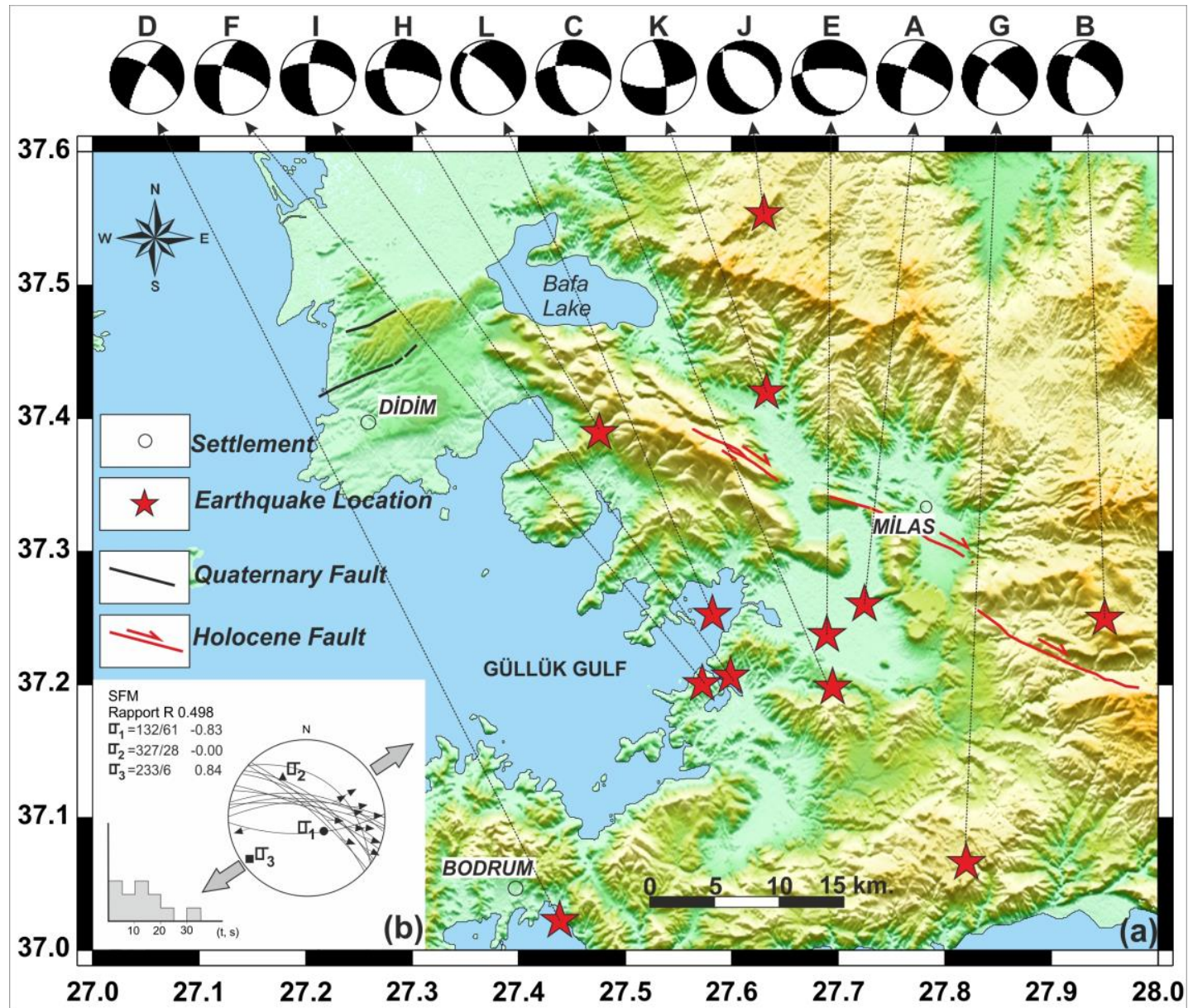

Figure 7. Moment tensor solutions for 12 earthquakes $(M>3.0)$ in Güllük Gulf and surroundings occurring on land and sea. b) SFM defines the results of the inversion.

Table 3.

Parameters of the focal mechanism results of the bigger than 3.0 magnitude earthquakes (FM: first motion).

\begin{tabular}{|c|c|c|c|c|c|c|c|c|c|}
\hline Name & Date & $\begin{array}{c}\text { Time } \\
\text { (UTM) }\end{array}$ & $\begin{array}{c}\text { Lat } \\
\text { (Degree) }\end{array}$ & $\begin{array}{c}\text { Long } \\
\text { (Degree) }\end{array}$ & $\begin{array}{c}\text { NP1 } \\
\text { (Strike-Dip-Rake) }\end{array}$ & $\begin{array}{c}\text { NP2 } \\
\text { (Strike-Dip-Rake) }\end{array}$ & Mag. & $\begin{array}{c}\text { Depth } \\
(\mathbf{k m})\end{array}$ & $\begin{array}{c}\text { Varience } \\
\text { Redaction }\end{array}$ \\
\hline A & 3.8 .2004 & $05: 33: 38$ & 27.72 & 37.26 & 293/78/-159 & $199 / 69 /-13$ & 4.2 & 20 & 61.47 \\
\hline B & 4.8.2004 & 04:19:50 & 27.95 & 37.25 & $305 / 62 /-138$ & $191 / 53 /-36$ & 4.9 & 20 & 70.11 \\
\hline $\mathrm{C}$ & 4.8.2004 & $04: 26: 26$ & 27.69 & 37.20 & $276 / 64 /-141$ & $166 / 55 /-33$ & 4.0 & 14 & 68.00 \\
\hline $\mathrm{D}$ & 4.8.2004 & 18:49:00 & 27.44 & 37.02 & $208 / 77 /-24$ & $303 / 67 /-165$ & 3.7 & 20 & 70.76 \\
\hline $\mathrm{E}$ & 5.8.2004 & $07: 11: 13$ & 27.69 & 37.24 & $270 / 69 /-120$ & $148 / 36 /-37$ & 3.8 & 10 & 79.94 \\
\hline $\mathrm{F}$ & 5.8 .2004 & $07: 13: 38$ & 27.58 & 37.20 & 289/72/-152 & $190 / 63 /-20$ & 4.0 & 22 & 75.26 \\
\hline $\mathrm{G}$ & 11.1 .2005 & $08: 33: 35$ & 27.82 & 37.08 & $310 / 80 /-146$ & $213 / 56 /-12$ & 3.7 & 16 & 56.19 \\
\hline $\mathrm{H}$ & 10.3.2008 & $17: 22: 24$ & 27.47 & 37.39 & 278/74/-137 & $174 / 49 /-21$ & 3.2 & 12 & 61.34 \\
\hline I & 3.5.2009 & $23: 25: 00$ & 27.60 & 37.21 & $178 / 70 /-33$ & 280/59/-156 & 3.1 & 18 & 66.67 \\
\hline $\mathrm{J}$ & 30.6 .2013 & $16: 57: 50$ & 27.64 & 37.55 & $149 / 53 /-78$ & $309 / 39 /-105$ & 3.3 & 6 & 58.64 \\
\hline $\mathrm{K}$ & 1.1.2014 & $06: 27: 48$ & 27.63 & 37.42 & $170 / 77 /-23$ & $86 / 68 /-165$ & 3.0 & 5 & FM \\
\hline $\mathrm{L}$ & 6.2 .2015 & $19: 37: 07$ & 27.58 & 37.25 & $313 / 74 /-110$ & $187 / 26 /-39$ & 3.1 & 6 & 51.68 \\
\hline
\end{tabular}


Based on kinematic analysis of fault assemblages, there are studies differentiating tectonic regime types and deformation stages in west central Anatolia. Some of these works are as follows, from west to east. A study in western Anatolia in the Cumaovası Basin near İzmir observed a transpressional regime along the Orhanl1 Fault Zone and left lateral strike slip faulting associated with NE/SW extension and NW/SE compression. Young data from the basin showed a transtensional regime related to $\mathrm{E} / \mathrm{W}$ oriented compression and N/S oriented extension was effective and they supported the continuation of this regime to the present with earthquake focal mechanism solutions (Uzel \& Sözbilir, 2008). In the İzmir Balıkesir Transfer Zone, 3 different deformation stages were identified of (i) $\mathrm{E} / \mathrm{W}$ compression and $\mathrm{N} / \mathrm{S}$ extension equivalent to the Miocene period, (ii) transitional stage from transtensional regime dominated by strike slip faulting to transtensional regime dominated by expansion in the Early Pliocene period and (iii) transformation to a narrow shear zone fragmenting the İzmir Balıkesir Transfer Zone during a deformation stage when NE/SW right lateral strike slip faults, NW/SE left lateral strike slip faults and E/W striking normal faults operated together (Uzel, Sözbilir, Özkaymak, Kaymakc1 \& Langereis, 2013). Three different deformation stages were identified for the Havran-Balıkesir Fault Zone; (i) NE/SW-NW/SE extension compression regime in the preMiocene period, (ii) N/S compression and E/W extension regime in the PlioQuaternary and (iii) NE-SW extension and NW/SE compression effective from the Quaternary to the present (Sümer, Uzel, Özkaymak \& Sözbilir, 2018). Within the scope of kinematic analysis studies of the Eskişehir Fault and surroundings located in west-central Anatolia, transition from NW/SE compression and NE/SW extension associated with a transpressional regime to NE/SW compression and NW/SE extension related to a transtensional tectonic regime probably occurred in the Quaternary time interval and this regime was proven to continue at present with earthquake focal mechanism solutions (Özden, Gündoğdu \& Bekler, 2015).

In this study faults were monitored directly, and kinematic data were not collected. In order to reveal the regional behavior mode, attempts were made to examine all outcrops where mesoscopic fault planes were observed. In an area, the presence of young units has great importance to interpret behavior. In situations without them, deformation in older units may be assessed. Results emerging from all data collected from the field and after assessment were conceptualized from the present day toward the past beginning with seismological data. For this reason, the results do not just represent active faults, but all of the Gulf of Güllük and close surroundings. In conclusion, the region can be said to be in an extensional regime producing mainly oblique strike normal faulting at present.

The detected NW/SE extension and NE/SW compression can be evaluated in the same phase. It may be interpreted as a compressive regime progressively transitioning to an extensional regime. Due to the extension in kinematic data being consistent with the present regime, it appears appropriate to interpret the compressional regime as being just before the present regime. However, though faults noted by MTA on the active tectonic map are shown as strike slip, areas close to these faults were observed to have more dominant vertical slip than strike slip on mesoscopic fault planes in the field. Kinematic solutions have the quality of supporting these results. In summary, it appears that faults in this field mostly have oblique-slip character. While some have dominant strike slip, most were identified to have dominant vertical slip character and the geodynamic evolution was interpreted based on this.

Results of SS2 obtained by this study, representing the youngest tectonic regime type from both kinematic analysis results, and the directions of expansion obtained from the focal mechanism common solution results of earthquakes, W-SW is compatible with the direction of expansion that is active in Anatolia today. In addition, these studies are compatible with the results of similar studies in the literature, especially in Western Anatolia (Figure 8).

Additionally, when locations for kinematic data obtained from field observations are examined, areas not located on or near the Milas Fault at these observation points were considered to be probable faults. Within this scope, it is considered there may be a possible extension of the Milas Fault toward the NW and a possible active fault at the north edge of the basin located south of Milas. It is necessary to investigate these 
faults with advanced and multidisciplinary studies like high-resolution shallow geophysics, paleoseismology and microseismic network studies to determine whether they are active faults or not.

\begin{tabular}{|c|c|c|}
\hline Age & Inversion of Fault and Eartquake & Deformation \\
\hline 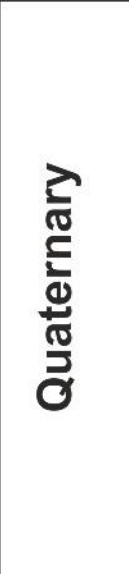 & $\begin{array}{c}\text { SS.2 } \\
\text { (Site } 6 \text { and } 7)\end{array}$ & $\begin{array}{l}\text { Normal to oblique } \\
\text { faulting } \\
\text { Ss.2: Site } 6 \text { and } 7 \\
\text { Eartquake: Total } 12 \text { pieces (A-L) }\end{array}$ \\
\hline 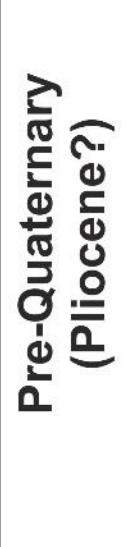 & (NW-SE Compression) & $\begin{array}{c}\text { Strike-Slip } \\
\text { faulting } \\
\text { (Mainly dextral with } \\
\text { WNW-ESE direction) } \\
\text { SS.1: Site } 1-5 \text { and } 8-19\end{array}$ \\
\hline
\end{tabular}

Figure 8. The Late Cenozoic stress states of the study area.

The N/S, NNE/SSW and occasionally NE/SW oriented and active extensional regime directions emerge as a result of the complicated relationship between the African plate and the Anatolian plate. Tears occurring at depth along the African plate cause rapid deformation of the overlying Anatolian plate.

\section{Conclusion}

In this study, kinematic and seismotectonic features of the Gulf of Güllük and close surroundings were investigated. A total of 136 faults with kinematic markers were reviewed at 21 stations and numerical analysis was performed. As a result, the presence of a two-stage tectonic regime representing the PlioQuaternary period was identified in the region. These are, from older to younger, NW/SE compression (SS1) and NE/SW extension (SS2) deformation stages. Considered to belong to the period before the Quaternary, the NW/SE compression (SS1) regime had compression direction $(\sigma 1)$ calculated as $\mathrm{N} 44^{\circ} \mathrm{W}$ and was concluded to involve close to pure strike slip faulting with $\mathrm{R}$ ratio between $0.45-0.55$ ( $\mathrm{R}=0.426)$. The NE/SW extensional regime considered to belong to the Quaternary period had extensional (opening) direction $(\sigma 3)$ calculated as $\mathrm{N}^{\circ} 0^{\circ} \mathrm{E}$. According to common solution results for earthquake focal mechanisms, currently there is an extensional regime with $\mathrm{NE} / \mathrm{SE}$ direction dominant in the region, with extensional (opening) direction (б3) of $\mathrm{N} 53^{\circ} \mathrm{E}$. Both the kinematic analysis results for the youngest tectonic regime of SS2 and the 
extensional direction obtained from common solution results for earthquake focal mechanisms are compatible with the current extensional direction affecting W-SW Anatolia.

\section{Acknowledgement}

This work was supported by Çanakkale Onsekiz Mart University The Scientific Research Coordination Unit, Project number: FHD-2018-2536

\section{Author Contributions}

Erdem Gündoğdu: The researcher contributed to field studies and kinematic analysis. He also put pen the manuscript paper.

Alper Demirci: The researcher contributed to seismological processes of the study.

Süha Özden: The researcher contributed to field studies and kinematic analysis.

\section{Conflicts of Interest}

The authors declare no conflict of interest.

\section{References}

Angelier, J. \& Mechler, P. (1977). Sur Methode Graphique de Recherche des Contraintes Princ. Egalement Utilisable en Tectonique et en Sismologie: la Methode Diédre Droit, Bulletin de la Société Geologique de France, 19, 1309-1318. https://doi.org/10.2113/gssgfbull.S7-XIX.6.1309

Carey, E. (1979). Recherche des Directions Principales de Contraintes Associées au jeu d'une Population de Failles, Revue Geological Dynamic and Géography physic, 21, 57-66.

Carey-Gailhardis, E. \& Mercier, J. L. (1987). A numerical Method for Determining the State of Stress Using Focal Mech. of Earthquake Populations: application to Tibetan teleseisms and microseismicity of Southern Peru. Earth and Planetary Science Letters. 82, 165-179. https://doi.org/10.1016/0012821X(87)90117-8

Dreger, D. (2002). Manual of the Time-Domain Moment Tensor Inverse Code (TDMT_INVC), Release 1.1. Berkeley Seismology Laboratory. pp. 18.

Dreger, D.S. \& Helmberger, D.V. (1993). Determination of source at regional distances with single stations or sparse network data, Journal of Geophysical Research Atmospheres, 98, 8107-8125. https://doi.org/10.1029/93JB00023

Duman, T.Y., Emre, Ö., Özalp, S. \& Elmacı, H., (2011). Türkiye Diri Fay Haritası Serisi, 1:250.000 Ölçekli Aydın (NJ 35-11) Paftası, Seri No:7, Maden Tetkik ve Arama Genel Müdürlüğü, Ankara-Türkiye.

Emre, Ö., Duman, T. Y., Özalp, S. \& Elmac1, H. (2011). 1:250.000 Ölçekli Türkiye Diri Fay Haritası Serisi, Denizli (NJ 35-12) Paftas1, Seri No:12, Maden Tetkik ve Arama Genel Müdürlüğü, Ankara Türkiye.

Emre, Ö., Duman, T. Y., Özalp, S., Şaroğlu, F., Olgun, Ş., Elmac1, H. \& Can, T. (2018). Active fault database of Turkey. Bulletin of Earthquake Engineering 16 (8), 3229-3275. https://doi.org/10.1007/s10518-016-0041-2

Kadiroğlu, F. T., Kartal, R. F., Kılıç, T., Kalafat, D., Duman, T. Y., Eroğlu-Azak, T., Özalp, S. \& Emre, Ö. (2018). An Improved Earthquake Catalogue (M >= 4.0) for Turkey and Its Near Vicinity (1900-

2012). Bulletin of Earthquake Engineering, 16, 8, 3317-3338. https://doi.org/10.1007/s10518-016-0064-8

Karabacak, V. (2016). Seismic damage in the Lagina sacred area on the Mugla Fault: a key point for the understanding of the obliquely situated faults of western Anatolia. Journal of Seismology, 20 (1), 277-289. https://doi.org/10.1007/s10950-015-9526-8

Kırkan, E., Akyüz, H. S., Zabcı, C., Basmenji, M., Dikbaş, A., Yazıcı, M., Aksoy, M. E., Uçarkuş, G. \& Yakupoğlu, N. (2017). Milas Fayı'nın Paleosismolojik, Morfotektonik ve Depremsellik Özelliklerine Dair İlk Bulgular. Aktif Tektonik Araştırma Grubu 21. Çalıştayı. 26-28 Ekim 2017, s51.

Lee, W. H. K. \& Lahr, J. C. (1972). HYPO71: a computer program for determining hypocenter, magnitude and first-motion pattern of local earthquakes, U.S. Geological survey open-file report, pp. 100 https://doi.org/10.3133/ofr72224 
Özden, S., Över, S., Kavak, K. Ş. \& İnal, S. S. (2008). Late Cenozoic stress states around the Bolu Basin along the North Anatolian Fault, NW Turkey. Journal of Geodynamics. vol.46, pp.48-62. https://doi.org/10.1016/j.jog.2008.04.004

Özden S., Gündoğdu E. \& Bekler T. (2015). "Interactions between Eurasian/African and Arabian plates: Eskişehir Fault, NW Turkey", Journal of African Earth Sciences, pp.1-19. https://doi.org/10.1016/j.jafrearsci.2015.08.014

Sümer, Ö., Uzel, B., Özkaymak, Ç. \& Sözbilir, H. (2018). Kinematics of the Havran-Balıkesir Fault Zone and its implication on geodynamic evolution of the Southern Marmara Region, NW Anatolia. Geodinamica Acta 30 (1), 306-323. https://doi.org/10.1080/09853111.2018.1540145

Şengör, A. M. C. (1980). Türkiye'nin Neotektoniğinin Esasları (Fundamentals of Neotectonics of Turkey). Geological Society of Turkey, Conference Series 2(in Turkish).

Tan, O., Tapırdamaz, M. C. \& Yörük, A. (2008). The earthquake catalogues for Turkey. Turkish Journal of Earth Sciences, vol.17, no.2, 405-418.

Uzel, B. \& Sözbilir, H. (2008). A first record of a strike-slip basin in western Anatolia and its tectonicimplication: the Cumaovas1 Basin. Turkish Journal of Earth Sciences 17 (3), 559-591.

Uzel, B., Sözbilir, H., Özkaymak, Ç., Kaymakcı, N. \& Langereis, C. G. (2013). Structural evidence for strike-slip deformation in the İzmir-Balıkesir transfer zone and consequences for late Cenozoic evolution of western Anatolia (Turkey). Journal of Geodynamics 65, 94-116. . https://doi.org/10.1016/j.jog.2012.06.009

Yılmazer, M. (2003). Deprem kaynak parametrelerinin Online Belirlenmesi. İstanbul Üniversitesi, Fen Bilimleri Enstitüsü, Yüksek Lisans Tezi, 47 s, İstanbul (Turkish) 